International Journal of English Literature and Social Sciences
Vol-6, Issue-4; Jul-Aug, 2021

Peer-Reviewed Journal

\title{
Non-intellective Challenges in Oral Communication Skills among Grade 11 Learners
}

\author{
Mylene F. De Guzman ${ }^{1}$, Dr. Fhrizz S. De Jesus ${ }^{2}$
}

${ }^{1}$ Sto. Domingo National High School, Baloc, Talavera, Nueva Ecija, Philippines

${ }^{2}$ College of Management and Business Technology, Nueva Ecija University of Science and Technology, Palayan City, Philippines

Received: 13 Jun 2021; Received in revised form: 07 Jul 2021; Accepted: 17 Jul 2021; Available online: 25 Jul 2021

(C)2021 The Author(s). Published by Infogain Publication. This is an open access article under the CC BY license

(https://creativecommons.org/licenses/by/4.0/).

\begin{abstract}
The child of today is the adult of tomorrow. His experiences today will make what he will be in the future. Pleasant experiences will lead him to become a confident person. However, unpleasant experiences may traumatize him and lead him to be a broken person. Some of the unpleasant experiences that a child may experience are coming from friends, classmates, schoolmates, teachers, family members, or people they interact with. They may leave negative marks which leave a negative impact on a child's communication skills and his personality as a whole. This study attempted to determine the nonintellective challenges in oral communication skills of grade 11 learners in Sto. Domingo National Trade School during School Year 2017-2018. The data were gathered from 206 Senior High School Grade 11 learners. To determine the total respondents, the sample and sampling procedures were employed. The Descriptive method of research was used in this study.The non-intellective challenges in oral communication skills of grade 11 learners include: peer factor, teacher factor, and family factor. Pearson $R$ correlation analysis was used to test the relationships between the profile of the respondents and the non-intellective factors in oral communication skills of the respondents. After finding out the results of this research study, a Project proposal to address the non-intellective challenges in oral communication skills among grade 11 learners was offered.
\end{abstract}

Keywords-Non-Challenges, Oral Communication, Learners, Bullying, Education.

\section{INTRODUCTION}

The child of today will become the adult of tomorrow. His experiences today will make what he will be in the future. Pleasant experiences will lead him to become a confident person. However, unpleasant experiences may traumatize him and lead him to be a broken person. Some of the unpleasant experiences that a child may experience are coming from friends, classmates, schoolmates, teachers, family members, or people they interact with. They may leave negative marks and big negative impact on a child's communication skills and his personality as a whole.

Undoubtedly, communication is indeed the greatest gift from God. Humans are born to express ideas, feelings, thoughts, words, and wisdom. Without communication, the world will be like a big round ball of chaos. According to
Ang (2015), man is a social being. This is the reason why humans have to get along with people every day. More so, Gupit (2011) stressed that an individual who lives in a society cannot get along with his fellowmen without some form of communication, and by its nature, oral communication. Furthermore, Nocom (2009) stated that language is the lifeblood of communication and the presentation of man to communicate with other people around him. It is highly individual; while it grows and changes through time it differs in place and situation.

As has been stated, communication's function is not only for human interaction. Jose and Larioque (2016) explained that the functions of communications are to: control, inform, emotionally express, and motivate. They also added communication which plays significant roles such 
as 1) to give order or command, to maintain peace and orderliness of society. Effective communication acts as controller to someone's behavior in several ways; 2) Communication gives information. People need to watch movies read newspapers and magazines, share, post some helpful ways or tips on a certain topic on Facebook or Twitter account which are definitely pieces of information.

3) Effective communication gives a release for emotional expression of feelings and fulfillment of social needs. 4) Motivation affects people's behavior and ability to accomplish goals. The parents or guardians who encourage their children to work hard and achieve something for their dream is exactly how communication becomes a vehicle to motivate a person.

Another aspect of oral communication, Tapalla and Tapalla (2009) said that speech can affect one's personality, one way to get ahead in this world is to possess good speaking skills and people who have this skill are ahead of others. Similarly, the words that a person speaks are reflections of his or her personalities. They are the result of one's thoughts, feelings, values, and attitudes.

To be good and successful communicators, the speaking skill should be honed first with proper education. Proper practices and trainings should be done before to come up with the excellent product of a communicator. Teaching oral communication in schools is becoming more infrequent. The importance of oral communication should be no different than the necessity of Mathematics, Reading, or Writing. In the field of education, Mazzerella (2012) said that oral communication is an important skill because it promotes leadership and confidence. When leaners are confident in their abilities they will succeed academically and socially.

The reason why students are reluctant in participating in classes especially in oral recitation is that they are experiencing communication apprehension and anxiety. Actually, Chavez, Neri, Paguio, and Tabotabo (2012) considered the speaking anxiety as "stage fright". This sensation occurs thousands of times daily. Tapalla and Tapalla (2009) as well as Khan (2015), stressed that poor speakers who lack poise and confidence hesitate and stammer when giving their talks. This tend to lessen selfconfidence. This is the type of shyness characterized by fear or apprehension about communicating orally.

Deeper analysis shows that this is the anatomy of platform stage fright: shyness, inexperience, unpreparedness, indecisiveness of the speech, and fear of the unknown (Gupit, 2011).

Moreover, this study also showed that levels of apprehension are due to anxiety experienced in previous events. Past anxious behaviors cause the individual to anticipate similar behaviors in future performances or, some unpleasant experiences may badly affect his confidence to become a good speaker.

In another point of view, some factors why learners have low self-concept is caused by bullying. They are being bullied by different persons around them. They may begin at home from parents, siblings, relatives, or other persons whom the learners consider as members of the family. A second factor which may be considered may come from the schools such as classmates, friends, schoolmates or even teachers. Surprisingly, based on The Bullying in the Philippines (2016), one out of two Filipino children have witnessed violence or abuse in their schools. The Philippines is a witness to different types of bullying including name calling, teasing, or forcing the victims to do things. The Department of Education in the Philippines reported more than 1,700 cases of child abuse or bullying in schools for the years 2013 and 2014. To augment the conclusions, bullying has a serious effect to children. Kolk, McFarlane, and Weisaeth (2007), stated that trauma in childhood can disrupt normal cognitive and psychological development of the victims. Many of the children who are affected by traumatic stressors such as bullying can have their developmental processes and parts of their brains affected by the traumatic events. Thus, oral communication skills of a learner could badly affect by bullying.

Despite the importance of communication, few people know about the number of children who struggle to develop these skills and the barriers they face. According to Boss (2016), in areas of poverty, more than half of the children start school with delayed language. They may struggle to understand or to make themselves understood; have smaller vocabulary; and have poor listening and social skills. One of the major challenges for these children and their families is that often, their difficulties are invisible to other people, as there is a lack of understanding of speech, language and communication needs.

Furthermore, people see clearly the impact of speech, language and communication needs-poor behavior, poor speaking, reading, and writing, isolated children, children with low confidence - but they do not see the underlying cause, poor-understanding and poor use of language and communication.

Jose and Larioque (2016) have suggested that to be a good communicator, one should possess effective communication skills. To become a better speaker, a communicator should plan the message before speaking; be considerate; speak clearly; stay focused on the conversation; be brief; and learn to "read" the listener. 
More so, to be a better listener, one should eliminate distraction; make time to listen; practice effective listening; listen for understanding; ask questions skillfully; wait for the speaker to finish; and pay attention to what is being said.

Tapalla and Tapalla (2009) said that there are several cures to improve self-confidence and manage speech anxieties such as: forget the people in front, never be self-conscious, be relaxed, and prepare the speech thoroughly.

In the same way, Chavez et al. (2012) suggested that there are common ways to diminish the negative effects of anxiety: 1) Depersonalization- keeps the centrality of the arguments in the forefront of his or her mind while delivering a speech and does not allow a speech to become an opportunity for the audience to assess the moral worth,

2) Behavior Modification - the beginning of the speech is the most comfortable part of the speech, and 3) Practicing good posture- to minimize obvious anxiety.

Despite different actions, solutions and remedies made by governments, schools, and other agencies in the country and all over the world, regardless of countless books, magazines, articles, and researches published to eliminate external factors which may give negative effects to oral communication skills of a person, this endless problem is not totally eradicated.

Therefore, the researchers were eager and interested to find-out the non-intellective challenges in oral communication skills among grade 11 learners. De Jesus et. Al. (2021), Public school teachers play an important role in our society, especially for the students. Teachers used classroom instructions and presentations to help the students learn and apply different concepts especially for the development of the students' communication skills. Del Villa (2010) cited that the fearful experiences with classmates and teachers hinder the development of learners' communication skills. In this study, the researchers selected to add family factor to find out if the parents or other family members may also hinder learners' communication development. Such non- intellective challenges in this research are: peer factor, teacher factor, and family factors.

\section{METHODOLOGY}

\section{a. Research Design}

The study adapted the Descriptive method of research which based on Singh (2010) is described as appropriate for studies to describe the characteristics or effects of events for an identified population. Furthermore, it aims to find out what prevails in present conditions or relationships, held opinions and beliefs, processes and effects and developing trends. A Descriptive research seeks to determine the relationship between variables, explores causes of phenomena, test hypotheses, and develops generalizations, principles or theories on the basis of its findings.

\section{b. Research Locale}

The research was conducted in Sto. Domingo National Trade School (SDNTS), Baloc, Nueva Ecija, Philiipines. The includes the Grade 11 learners of Sto. Domingo National Trade School in S.Y. 2017- 2018. The sample and sampling procedures were employed by the researcher.

\section{c. Sampling}

The primary subjects were chosen using purposive sampling. They were chosen based on judgment and the research's goal. Participants were chosen based on their personal encounters with the phenomenon. The total population of this study was 423 with a sample size of 206. The researchers used Raosoft application with 95\% confidence level and 5\% error of margin.

\section{d. Data Gathering}

The research instrument used was survey method and interview, wherein respondents answered questions administered through questionnaires and interviews.

The researchers' mentors double-checked the questionnaire after it was prepared using the data gathered. A pilot testing was conducted. The dependability coefficient of the instrument was calculated and found to be .820 suggesting that it has good internal consistency. The research instrument's validity was validated by submitting it to experts for comment, who gave it a 4.40 weighted mean and a verbal interpretation of "very good." The completed questionnaires were gathered after distribution, and the data was tallied for analysis.

The researchers personally administered the questionnaires to the student-respondents. The objectives of the study were clearly explained to respondents. She clarified all the directions and all parts in the questionnaires in order to get their full cooperation as well as get just and objective results of the research.

After successfully answering the questionnaire, the researchers retrieved the all questionnaires to maintain the accuracy and validity of the results.

\section{e. Data Analysis}

The data gathered presented, analyzed and interpreted using frequency counts, percentage, weighted mean and Pearson R Correlation Analysis. 
To assess the non-intellective challenges on oral communication skills among the respondents, weighted mean was used. For verbal interpretation of the weighted mean, a 4 point Likert scale was used.

To describe the profile of the respondents, frequency count and percentage were used.

Pearson $\mathrm{R}$ was used to test the relationship between the profile variables of the respondents and their nonintellective challenges on oral communication skills.

\section{RESULTS AND DISCUSSIONS}

\subsection{Profile of the respondents}

\subsubsection{Age of the Respondents}

Table 1. Age of the respondents

\begin{tabular}{|l|l|l|}
\hline Age & Frequency (f) & Percentage (\%) \\
\hline 15 years old & 7 & 3 \\
\hline 16 years old & 113 & 55 \\
\hline 17 years old & 78 & 38 \\
\hline 18 years old & 6 & 2 \\
\hline 19 years old & 1 & 1 \\
\hline 20 - above & 1 & 1 \\
\hline Total & 206 & 100.00 \\
\hline
\end{tabular}

Table 1 shows the age of the respondents. As shown in the table, the respondents who were 16 years old comprised of 113 or 55 percent, however, there was only one respondent or 1 percent for ages 19 and 20 years and above.

Based on the above data, the result may be interpreted that 16 years old dominated the number of the respondents which deemed appropriate for grade 11 learners.

According to the Department of Education (2017), at age of 16, learners should be Grade 11 (First Year Senior High School).

\subsubsection{Sex of the Respondents}

Table 2. Sex of the respondents

\begin{tabular}{|c|c|c|}
\hline Sex & $\begin{array}{c}\text { Frequency } \\
(\mathbf{f})\end{array}$ & $\begin{array}{c}\text { Percentage } \\
(\boldsymbol{\%})\end{array}$ \\
\hline Male & 105 & 51 \\
\hline Female & 101 & 49 \\
\hline Total & $\mathbf{2 0 6}$ & $\mathbf{1 0 0 . 0 0}$ \\
\hline
\end{tabular}

The second item on the profile of the respondents is sex where 105 or 51 percent were males and 101 or 49 percent were females from the 206 total respondents.
The above statistics indicates that there was minimal difference in terms of male and female respondents.

Based on the Philippine Education for All Review Report (2015), global gender gap index reported that the Philippines is fifth in rank and is the only country in Asia and the Pacific to close the gender gap both in health and education. Moreover, it stated that gender parity in elementary and secondary education was met.

\subsubsection{Junior High School Completed Forms}

Another factor considered under the profile of the respondents is the type of high school they completed from. As illustrated in table 5, Out of 206 respondents, 188 or 91 percent outnumbered junior high school completers from public schools, and only 18 or 9 percent completed their junior high school from private schools.

Table 3. Junior High School Completed Forms

\begin{tabular}{|c|c|c|}
\hline $\begin{array}{c}\text { Junior High } \\
\text { School } \\
\text { Completed } \\
\text { from }\end{array}$ & $\begin{array}{c}\text { Frequency } \\
\text { (f) }\end{array}$ & $\begin{array}{c}\text { Percentage } \\
(\%)\end{array}$ \\
\hline Public School & 188 & 91 \\
\hline Private School & 18 & 9 \\
\hline Total & $\mathbf{2 0 6}$ & $\mathbf{1 0 0 . 0 0}$ \\
\hline
\end{tabular}

The figures above simply indicate that most senior high school learners completed junior from public school. This is because public schools do not charge tuition fees so that parents are able to send their children to avail of education.

\subsubsection{General Average in Grade 10}

Table 4. General Average in Grade 10

\begin{tabular}{|c|l|c|c|}
\hline $\begin{array}{c}\text { General } \\
\text { Average in } \\
\text { Grade 10 }\end{array}$ & $\begin{array}{c}\text { Verbal } \\
\text { Interpretation }\end{array}$ & $\begin{array}{c}\text { Frequency } \\
\text { (f) }\end{array}$ & $\begin{array}{c}\text { Percentage } \\
(\%)\end{array}$ \\
\hline $90-100$ & Outstanding & 43 & 21 \\
\hline $85-90$ & $\begin{array}{l}\text { Very } \\
\text { Satisfactory }\end{array}$ & 59 & 29 \\
\hline $80-84$ & Satisfactory & 95 & 46 \\
\hline $75-79$ & $\begin{array}{l}\text { Fairly } \\
\text { Satisfactory }\end{array}$ & 9 & 4 \\
\hline Total & & $\mathbf{2 0 6}$ & $\mathbf{1 0 0 . 0 0}$ \\
\hline
\end{tabular}

The table illustrates the distribution of the respondents as to their general average in grade 10 . There were 95 or 46 percent who obtained general average of $80-84$ or 
Satisfactory; and nine or 4percent were in the grade bracket of 75-79 or Fairly Satisfactory.

The results suggest that majority of learners' academic achievements in grade 10 were satisfactory. This was explained by American Psychological Association (2017), wherein children from low-income families enter high school with average literacy skills.

According to the study of Borje (2007), academic competence on the part of the students is an important tool to succeed in their formal pursuit and social mobility in the future. He also added that in most cases, academic performance of students is also determined by their ability and command in the use of the language.

\subsubsection{Educational Attainment of the Parents}

The table reflects the parents' educational attainment of the respondents. In father's educational attainment, it clearly states that high school graduates dominated the number of respondents. It obtained a total of 67 or 33 percent and only one or 1 percent Graduated with a Doctoral degree.

On the other hand, from the sum of 206 respondents, 70 or 34 percent of mother's educational attainment graduated in high school; and only two or 1 percent had graduated with Master's degrees.

The result is similar to the study of Frijas (2014) wherein majority of parents' educational attainment of her respondents did not finish any degree.

Actually, in Year 2010, about 69 percent of the household population in the Philippines aged 13 to 16 years reached or completed high school at most.

Table 5. Educational Attainment of the Parents

\begin{tabular}{|l|c|c|c|c|}
\hline \multirow{2}{*}{$\begin{array}{l}\text { Educational } \\
\text { Attainment }\end{array}$} & \multicolumn{2}{|c|}{ FATHER } & \multicolumn{2}{c|}{ MOTHER } \\
\cline { 2 - 5 } & $(\%)$ & (f) & $(\%)$ \\
\hline $\begin{array}{l}\text { Elementary } \\
\text { Undergraduate }\end{array}$ & 11 & 5 & 5 & 2 \\
\hline $\begin{array}{l}\text { Elementary } \\
\text { Graduate }\end{array}$ & 23 & 11 & 19 & 9 \\
\hline $\begin{array}{l}\text { High School } \\
\text { Undergraduate }\end{array}$ & 20 & 10 & 16 & 8 \\
\hline $\begin{array}{l}\text { High School } \\
\text { Graduate }\end{array}$ & 67 & 33 & 70 & 34 \\
\hline
\end{tabular}

\begin{tabular}{|l|c|c|c|c|}
\hline $\begin{array}{l}\text { College } \\
\text { Undergraduate }\end{array}$ & 36 & 17 & 42 & 20 \\
\hline College Graduate & 44 & 21 & 49 & 24 \\
\hline $\begin{array}{l}\text { Earned Units in } \\
\text { Master's Degree }\end{array}$ & 3 & 2 & 3 & 2 \\
\hline $\begin{array}{l}\text { Doctoral } \\
\text { Graduate }\end{array}$ & 1 & 1 & 2 & 1 \\
\hline \multicolumn{1}{|c|}{ Total } & $\mathbf{2 0 5}$ & $\mathbf{1 0 0 . 0 0}$ & $\mathbf{2 0 6}$ & $\mathbf{1 0 0 . 0 0}$ \\
\hline
\end{tabular}

Frijas (2014), stated that parents' educational qualification in bringing up well rounded individuals, do their part in providing for their children's needs. Parents should meet the physical, physiological, and emotional needs of their children. As it is said, parents are the children's first teachers who will motivate and teach children to boost confidence and face more complex lives ahead of them.

\subsubsection{Parents' Occupation}

As per table 9, it shows the parents' occupation of the respondents. With over 205 respondents, 66 or 32 percent were farmers which was the highest frequency of the father's occupation; and only one or 1 percent was nurse and clerk.

Table 6. Parents' Occupation

\begin{tabular}{|l|c|c|c|c|}
\hline \multirow{2}{*}{$\begin{array}{c}\text { Occupati } \\
\text { on }\end{array}$} & \multicolumn{2}{|c|}{ FATHER } & \multicolumn{2}{c|}{ MOTHER } \\
\cline { 2 - 5 } & $\begin{array}{c}\text { Frequen (f) } \\
\text { cy }\end{array}$ & $\begin{array}{c}\text { Percenta } \\
\text { ge (\%) }\end{array}$ & $\begin{array}{c}\text { Frequen } \\
\text { cy (f) }\end{array}$ & $\begin{array}{c}\text { Percenta } \\
\text { ge (\%) }\end{array}$ \\
\hline Teacher & 2 & 1 & 7 & 3 \\
\hline Nurse & 1 & 1 & 3 & 2 \\
\hline $\begin{array}{l}\text { Certified } \\
\text { Public } \\
\text { Accounta } \\
\text { nt }\end{array}$ & 0 & 0 & 1 & 1 \\
\hline Engineer & 4 & 2 & 0 & 0 \\
\hline Policeman & 2 & 1 & 0 & 0 \\
\hline $\begin{array}{l}\text { Technicia } \\
\text { n }\end{array}$ & 6 & 3 & 0 & 0 \\
\hline Clerk & 1 & 1 & 0 & 0 \\
\hline $\begin{array}{l}\text { Social } \\
\text { Worker }\end{array}$ & 8 & 4 & 1 & 1 \\
\hline Farmer & 66 & 32 & 4 & 2 \\
\hline Vendor & 5 & 2 & 9 & 4 \\
\hline
\end{tabular}




\begin{tabular}{|l|c|c|c|c|}
\hline $\begin{array}{l}\text { Business } \\
\text { man }\end{array}$ & 8 & 4 & 9 & 4 \\
\hline $\begin{array}{l}\text { Factory } \\
\text { Worker }\end{array}$ & 5 & 2 & 0 & 0 \\
\hline Driver & 31 & 15 & 1 & 1 \\
\hline $\begin{array}{l}\text { Domestic } \\
\text { Helper }\end{array}$ & 2 & 1 & 2 & 1 \\
\hline OFW & 14 & 7 & 34 & 15 \\
\hline $\begin{array}{l}\text { Unemploy } \\
\text { ed } / \\
\text { housekeep } \\
\text { er }\end{array}$ & 3 & 2 & 119 & 57 \\
\hline Others & 40 & 19 & 19 & 8 \\
\hline Deceased & 7 & 3 & 2 & 1 \\
\hline Total & $\mathbf{2 0 5}$ & $\mathbf{1 0 0 . 0 0}$ & $\mathbf{2 0 6}$ & $\mathbf{1 0 0 . 0 0}$ \\
\hline
\end{tabular}

According to Flora (2016) in Sun Star Pampanga, Central Luzon is the rice Granary of the Philippines. Nueva Ecija is considered a leading Palay producer since 1991 until Mindoro's claim that it is the current rice granary of the Philippines. The emerging of the house projects and multiple malls gave way to concretization instead of the rice fields the region formerly boasted of.

Meanwhile, unemployed or housekeepers had the highest number in mother's occupation of the respondents. It encompassed 119 or 57 percent; there was only one or 1percent respondent for the occupations Certified Public Accountant, and Social Worker.

Based on the context of Filipino culture, the role of women in the Philippines is that of housewife. (Reardon, Valintino, \& Shore, 2013).

\section{Non- Intellective Challenges in Oral Communication Skills of the Respondents.}

The second specific problem dealt with the non-

intellective challenges in oral communication skills among the Grade 11 learners as to peer factor, teacher factor, and family factor.

\section{1 . Non-Intellective Challenges In Oral Communication Skills In Terms Of Peer Factor}

Table 7 illustrates the non-intellective challenges in oral communication skills in terms of peer factor. It may be seen in the table that item 7, "My classmates/friends/ schoolmates make fun of me when I mispronounce words/ phrases." obtained the highest weighted mean of 3.02 and interpreted as "challenged" while item 11, "My classmates/friends/ schoolmates get angry with me when I use technical terms and terminologies not understood by them." obtained the lowest weighted mean of 2.56 and interpreted as "challenged".

Based on the findings above, it may be inferred that nonintellective challenges in oral communication skills among grade 11 learners in terms of peer factor acquired an average weighted mean of 2.76 and clearly interpreted as "challenged". This means that the learners are bothered and felt humiliated when they pronounced words/ phrases incorrectly. They considered it as most unpleasant experiences that negatively affected their communication skills. Kraus (2010) stated that when someone laughs and corrects one's grammar or word usage, shame and embarrassment are likely to be felt.

Table 7. Non-Intellective Challenges In Oral Communication Skills In Terms Of Peer Factor

\begin{tabular}{|c|c|c|c|}
\hline \multicolumn{2}{|c|}{$\begin{array}{l}\text { My classmates/Friends/ } \\
\text { Schoolmates... }\end{array}$} & $\begin{array}{l}\text { Weighted } \\
\text { Mean }\end{array}$ & $\begin{array}{l}\text { Verbal } \\
\text { Interpretation }\end{array}$ \\
\hline 1 & $\begin{array}{l}\text { say discouraging words } \\
\text { whenever I hardly } \\
\text { organize my thoughts } \\
\text { during oral recitation; }\end{array}$ & 2.66 & Challenged \\
\hline 2 & $\begin{array}{l}\text { show unwillingness to } \\
\text { listen while I am talking } \\
\text { in front of the class; }\end{array}$ & 2.81 & Challenged \\
\hline 3 & $\begin{array}{l}\text { underestimate me in } \\
\text { front of my other } \\
\text { classmates/ friends } \\
\text { whenever I am hesitant } \\
\text { to participate in oral } \\
\text { recitation; }\end{array}$ & 2.71 & Challenged \\
\hline 4 & $\begin{array}{l}\text { frown at me whenever I } \\
\text { answer their questions } \\
\text { incorrectly; }\end{array}$ & 2.86 & Challenged \\
\hline 5 & $\begin{array}{l}\text { shout at me whenever I } \\
\text { answer their questions } \\
\text { indirectly; }\end{array}$ & 2.63 & Challenged \\
\hline 6 & $\begin{array}{l}\text { get mad at me whenever } \\
\text { I dominate the } \\
\text { discussion in the class; }\end{array}$ & 2.60 & Challenged \\
\hline 7 & $\begin{array}{l}\text { make fun of me when I } \\
\text { mispronounce words/ } \\
\text { phrases; }\end{array}$ & 3.02 & Challenged \\
\hline 8 & $\begin{array}{l}\text { laugh at me when I use } \\
\text { wrong grammar; }\end{array}$ & 3.01 & Challenged \\
\hline 9 & $\begin{array}{l}\text { nag me whenever I am } \\
\text { distracted and find it } \\
\text { hard to listen to them; }\end{array}$ & 2.74 & Challenged \\
\hline 10 & ignore me whenever I & 2.86 & Challenged \\
\hline
\end{tabular}




\begin{tabular}{|c|c|c|c|}
\hline & $\begin{array}{l}\text { am suggesting } \\
\text { something; }\end{array}$ & & \\
\hline 11 & $\begin{array}{l}\text { get angry with me when } \\
\text { I use technical terms } \\
\text { and terminologies not } \\
\text { understood by them; }\end{array}$ & 2.56 & Challenged \\
\hline 12 & $\begin{array}{l}\text { insist that I am wrong } \\
\text { when I jump into } \\
\text { conclusion as if I } \\
\text { understood everything; }\end{array}$ & 2.87 & Challenged \\
\hline 13 & $\begin{array}{l}\text { shout at me when I } \\
\text { speak too fast or too } \\
\text { slow; }\end{array}$ & 2.67 & Challenged \\
\hline 14 & $\begin{array}{l}\text { say offensive words } \\
\text { when I use high pitch } \\
\text { during the conversation; } \\
\text { and }\end{array}$ & 2.78 & Challenged \\
\hline 15 & $\begin{array}{l}\text { say bad words against } \\
\text { me whenever I use } \\
\text { inappropriate non- } \\
\text { verbal communications } \\
\text { such as frowning, arms- } \\
\text { crossed, and focusing } \\
\text { my eyes to other things. }\end{array}$ & 2.66 & Challenged \\
\hline \multicolumn{2}{|c|}{ Average Weighted Mean } & 2.76 & Challenged \\
\hline
\end{tabular}

This was elucidated by Chavez et al. (2014), in their book Creative Oral Communication for Filipino Students: A Practical Application wherein they stated that it is not enough to know about a language that makes an individual competent. Communicative competence does not only entail one's excellent knowledge in grammar or grammatical competence. It encompasses linguistic discourse, sociolinguistic, and strategic competence. It is saying things correctly, connecting the string of information appropriately, saying it with respect to the person's unique personality and saying it properly in the right time. The knowledge on grammar will help a person create grammatical sentences that will enable him to communicate clearly but discourse competence present grammatical sentences with coherence and cohesion. Sociolinguistic competence enriches one's utterances when he employs his background knowledge of the person that he is speaking with.

\section{2 . Non-Intellective Challenges In Oral Communication Skills In Terms Of Teacher Factor}

Table 8. Non-Intellective Challenges In Oral Communication Skills In Terms Of Teacher Factor

\begin{tabular}{|c|c|c|c|}
\hline \multicolumn{2}{|c|}{ My teachers... } & $\begin{array}{l}\text { Weighted } \\
\text { Mean }\end{array}$ & $\begin{array}{l}\text { Verbal } \\
\text { Interpretation }\end{array}$ \\
\hline 1 & $\begin{array}{l}\text { say discouraging words } \\
\text { whenever I hardly } \\
\text { organize my thoughts } \\
\text { during oral recitation; }\end{array}$ & 2.06 & $\begin{array}{l}\text { Moderately } \\
\text { Challenged }\end{array}$ \\
\hline 2 & $\begin{array}{l}\text { interrupt me while I am } \\
\text { talking/ reciting in front } \\
\text { of the class; }\end{array}$ & 2.04 & $\begin{array}{l}\text { Moderately } \\
\text { Challenged }\end{array}$ \\
\hline 3 & $\begin{array}{l}\text { underestimate me in } \\
\text { front of my other } \\
\text { classmates whenever I } \\
\text { am hesitant to } \\
\text { participate in oral } \\
\text { recitation; }\end{array}$ & 1.93 & $\begin{array}{l}\text { Moderately } \\
\text { Challenged }\end{array}$ \\
\hline 4 & $\begin{array}{l}\text { frown at me whenever I } \\
\text { answer their questions } \\
\text { incorrectly; }\end{array}$ & 2.02 & $\begin{array}{l}\text { Moderately } \\
\text { Challenged }\end{array}$ \\
\hline 5 & $\begin{array}{l}\text { Neglect me whenever I } \\
\text { recite in front of the } \\
\text { class; }\end{array}$ & 1.87 & $\begin{array}{l}\text { Moderately } \\
\text { Challenged }\end{array}$ \\
\hline 6 & $\begin{array}{l}\text { get mad at me } \\
\text { whenever I dominate } \\
\text { the discussion in the } \\
\text { class; }\end{array}$ & 1.97 & $\begin{array}{l}\text { Moderately } \\
\text { Challenged }\end{array}$ \\
\hline 7 & $\begin{array}{l}\text { make fun of me when I } \\
\text { mispronounce English } \\
\text { words/ phrases; }\end{array}$ & 2.11 & $\begin{array}{l}\text { Moderately } \\
\text { Challenged }\end{array}$ \\
\hline 8 & $\begin{array}{l}\text { laugh at me when I use } \\
\text { wrong grammar; }\end{array}$ & 2.00 & $\begin{array}{l}\text { Moderately } \\
\text { Challenged }\end{array}$ \\
\hline 9 & $\begin{array}{l}\text { nag me whenever I am } \\
\text { distracted and find it } \\
\text { hard to listen to them; }\end{array}$ & 2.01 & $\begin{array}{l}\text { Moderately } \\
\text { Challenged }\end{array}$ \\
\hline 10 & $\begin{array}{l}\text { ignore me whenever I } \\
\text { am suggesting } \\
\text { something; }\end{array}$ & 2.08 & $\begin{array}{l}\text { Moderately } \\
\text { Challenged }\end{array}$ \\
\hline 11 & $\begin{array}{l}\text { get angry with me when } \\
\text { I use technical terms } \\
\text { and terminologies not } \\
\text { understood by them; }\end{array}$ & 1.84 & $\begin{array}{l}\text { Moderately } \\
\text { Challenged }\end{array}$ \\
\hline 12 & $\begin{array}{l}\text { insist that I am wrong } \\
\text { when I jump into } \\
\text { conclusion as if I } \\
\text { understood everything; }\end{array}$ & 2.05 & $\begin{array}{l}\text { Moderately } \\
\text { Challenged }\end{array}$ \\
\hline
\end{tabular}




\begin{tabular}{|c|l|l|l|}
\hline 13 & $\begin{array}{l}\text { shout at me when I } \\
\text { speak too fast or too } \\
\text { slow; }\end{array}$ & 1.88 & $\begin{array}{l}\text { Moderately } \\
\text { Challenged }\end{array}$ \\
\hline 15 & $\begin{array}{l}\text { say words against me } \\
\text { when I use high pitch } \\
\text { during the } \\
\text { conversation; and }\end{array}$ & 1.87 & $\begin{array}{l}\text { Moderately } \\
\text { Challenged }\end{array}$ \\
\hline $\begin{array}{l}\text { verbal communications } \\
\text { me whenever I use } \\
\text { inappropriate non- } \\
\text { crossed, and focusing } \\
\text { my eyes to other } \\
\text { things. }\end{array}$ & 1.66 & Unchallenged \\
\hline Average Weighted Mean & 1.96 & $\begin{array}{l}\text { Moderately } \\
\text { Challenged }\end{array}$ \\
\hline
\end{tabular}

In view of the foregoing, table 8 shows the non-intellective challenges in oral communication in terms of teacher factor. The same observation may be distinguished that item 7, "My teachers make fun of me when I mispronounce words/ phrases." obtained the highest weighted mean of 2.11 and interpreted as "Moderately Challenged", while item 15, "My teachers say bad words against me whenever I use inappropriate non-verbal communications such as frowning, arms- crossed, and focusing my eyes to other things." obtained the lowest weighted mean of 1.66 and interpreted as "Unchallenged".

In general, the non-intellective challenges in oral communication skills in terms of teacher factor obtained an average weighted mean of 1.96 and interpreted as "Moderately Challenged".

This means that the learners still experienced humiliation whenever teachers laugh at them if they commit mistakes in answering in oral communication activities.

Bullying is common among teachers in their own classrooms, where pupils are witness to the behavior. When students mispronounce phrases, they laugh, which can lead to embarrassment, which attracts attention while degrading a student in front of others.

Based on the findings of Nguyen (2011) in her study Factors Affecting the English Speaking Ability, she recommended that teachers should pay more attention on the social activities where learners can communicate openly with others learners, with foreigners, in English language and that teachers should apply the suitable intervention materials in order to enhance the English Speaking ability of the learners.

\subsection{Non-Intellective Challenges In Oral Communication Skills In Terms Of Family Factor}

Table. 9 Non-Intellective Challenges In Oral Communication Skills In Terms Of Family Factor

\begin{tabular}{|c|c|c|c|}
\hline \multicolumn{2}{|c|}{$\begin{array}{l}\text { My parents/other members } \\
\text { of my family... }\end{array}$} & \multirow{2}{*}{$\begin{array}{l}\text { Weighted } \\
\text { Mean } \\
\\
2.56\end{array}$} & \multirow{2}{*}{$\begin{array}{l}\text { Verbal } \\
\text { Interpretation } \\
\text { Challenged }\end{array}$} \\
\hline 1 & $\begin{array}{l}\text { say discouraging } \\
\text { words whenever I } \\
\text { hardly organize my } \\
\text { thoughts while } \\
\text { speaking to them; }\end{array}$ & & \\
\hline 2 & $\begin{array}{l}\text { interrupt me while I } \\
\text { am saying something; }\end{array}$ & 2.60 & Challenged \\
\hline 3 & $\begin{array}{l}\text { underestimate me in } \\
\text { front of other people } \\
\text { whenever I am hesitant } \\
\text { to speak; }\end{array}$ & 2.19 & $\begin{array}{l}\text { Moderately } \\
\text { Challenged }\end{array}$ \\
\hline 4 & $\begin{array}{l}\text { get angry with me } \\
\text { whenever I answer } \\
\text { their questions } \\
\text { incorrectly; }\end{array}$ & 2.65 & Challenged \\
\hline 5 & $\begin{array}{l}\text { scold me whenever I } \\
\text { answer their questions } \\
\text { indirectly; }\end{array}$ & 2.52 & Challenged \\
\hline 6 & $\begin{array}{l}\text { ask me to stay inside } \\
\text { the room or get away } \\
\text { whenever there are } \\
\text { guests; }\end{array}$ & 2.09 & $\begin{array}{l}\text { Moderately } \\
\text { Challenged }\end{array}$ \\
\hline 7 & $\begin{array}{l}\text { make fun of me when I } \\
\text { mispronounce English } \\
\text { words/ phrases; }\end{array}$ & 2.27 & $\begin{array}{l}\text { Moderately } \\
\text { Challenged }\end{array}$ \\
\hline 8 & $\begin{array}{l}\text { ask me to remain silent } \\
\text { whenever adults are } \\
\text { discussing; }\end{array}$ & 2.89 & Challenged \\
\hline 9 & $\begin{array}{l}\text { instruct me not to } \\
\text { explain my side } \\
\text { whenever confronted } \\
\text { because I am not } \\
\text { matured enough; }\end{array}$ & 2.65 & Challenged \\
\hline 10 & $\begin{array}{l}\text { ignore me whenever I } \\
\text { am suggesting } \\
\text { something; }\end{array}$ & 2.33 & $\begin{array}{l}\text { Moderately } \\
\text { Challenged }\end{array}$ \\
\hline 11 & $\begin{array}{l}\text { get angry with me } \\
\text { when I use technical } \\
\text { terms and } \\
\text { terminologies not } \\
\text { understood by them; }\end{array}$ & 2.36 & $\begin{array}{l}\text { Moderately } \\
\text { Challenged }\end{array}$ \\
\hline
\end{tabular}




\begin{tabular}{|l|l|l|l|}
\hline 12 & $\begin{array}{l}\text { say that I do not have } \\
\text { the right to join adult } \\
\text { conversation; }\end{array}$ & 2.65 & Challenged \\
\hline 13 & $\begin{array}{l}\text { shout at me when I } \\
\text { speak too fast or too } \\
\text { slow; and }\end{array}$ & 2.50 & Challenged \\
\hline 14 & $\begin{array}{l}\text { discourage me to be } \\
\text { assertive; and }\end{array}$ & 2.27 & $\begin{array}{l}\text { Moderately } \\
\text { Challenged }\end{array}$ \\
\hline 15 & $\begin{array}{l}\text { say that I am forbidden } \\
\text { to socialize with those } \\
\text { they do not know. }\end{array}$ & 2.34 & $\begin{array}{l}\text { Moderately } \\
\text { Challenged }\end{array}$ \\
\hline Average Weighted Mean & 2.46 & $\begin{array}{l}\text { Moderately } \\
\text { Challenged }\end{array}$ \\
\hline
\end{tabular}

As indicated in Table 9, the data presented is about the non-intellective challenges in oral communication in terms of family factor. It may be perceived in the table that item 8 , "My parents/ other members of my family ask me to remain silent whenever adults are discussing." got the highest weighted mean of 2.89 and interpreted as "Challenged", while item 6, "My parents/ other members of my family ask me to stay inside the room or get away whenever there are guests." obtained the lowest weighted mean of 2.09 and interpreted as "Moderately Challenged".

Based on the findings above, the non-intellective challenges in oral communication in terms of family factor obtained an average weighted mean of 2.61 and interpreted as "Moderately Challenged".

It is evident from the table that family is one of the important factors that affects the oral communication of their children. Learners are experiencing challenges from their family which may hinder them to be better oral communicators. Flores (2007) stated that parents are the first teachers at home. They are responsible for the development of values, attitudes and habits that will be needed to develop their communication to their peers.

In connection to the results above, Hays (2015) cited that in customs practiced in the Philippines, it is impolite to be noisy and pass between people conversing or facing one another especially adults. The findings may be interpreted as because of the Filipino cultures inherited from the ancestors, children should remain quiet and pay respect while adults are discussing.

\subsection{Summary Of The Non-Intellective Challenges In Oral Communication Skills Among Grade 11 Learners}

Table 10. Summary of The Non-Intellective Challenges In Oral Communication Skills Among Grade 11 Learners

\begin{tabular}{|l|l|l|l|}
\hline \multicolumn{2}{|l|}{$\begin{array}{l}\text { Non-Intellective } \\
\text { Challenges in Oral } \\
\text { Communication skills }\end{array}$} & $\begin{array}{l}\text { Average } \\
\text { Weighted } \\
\text { Mean }\end{array}$ & $\begin{array}{l}\text { Verbal } \\
\text { Interpretation }\end{array}$ \\
\hline 1 & Peer Factor & 2.76 & Challenged \\
\hline 2 & Teacher Factor & 1.96 & $\begin{array}{l}\text { Moderately } \\
\text { Challenged }\end{array}$ \\
\hline 3 & Family Factor & 2.46 & $\begin{array}{l}\text { Moderately } \\
\text { Challenged }\end{array}$ \\
\hline Grand Weighted Mean & 2.39 & $\begin{array}{l}\text { Moderately } \\
\text { Challenged }\end{array}$ \\
\hline
\end{tabular}

Table 10 shows the summary of the non-intellective challenges in oral communication skills. On one hand, it may be observed that peer factor has the highest average mean of 2.76 interpreted as "Challenged"; on the other hand, the teacher factor has the lowest average mean of 1.96 interpreted as "Moderately Challenged".

This clearly means that language can make or break a person. Specifically, spoken words can motivate and build someone's confidence, on the other hand, it may also ruin someone's life. Kukaswadia (2013) cited that language is incredibly powerful, and using language inappropriately can be damaging and offensive to people. This is subsequent with Jose and Larioque (2016) wherein they stated that like any powerful tool, language can cause selfinflected harm, hurt, misunderstanding and confusion.

Aside from this, verbal bullying which commonly happens in school can affect one's self image, and affect someone in emotional and psychological ways. This type of bullying can lead to low self-esteem, as well as depression and other problems. It can aggravate problems that a victim may already be experiencing at school. (Bullying Statistics, 2017).

\section{Correlation Analysis Among The Profile Of The Respondents And Their Non-Intellective Challenges In Oral Communication Skills}


Table 11. Correlation Analysis Among The Profile Of The Respondents And Their Non-Intellective Challenges In Oral Communication Skills

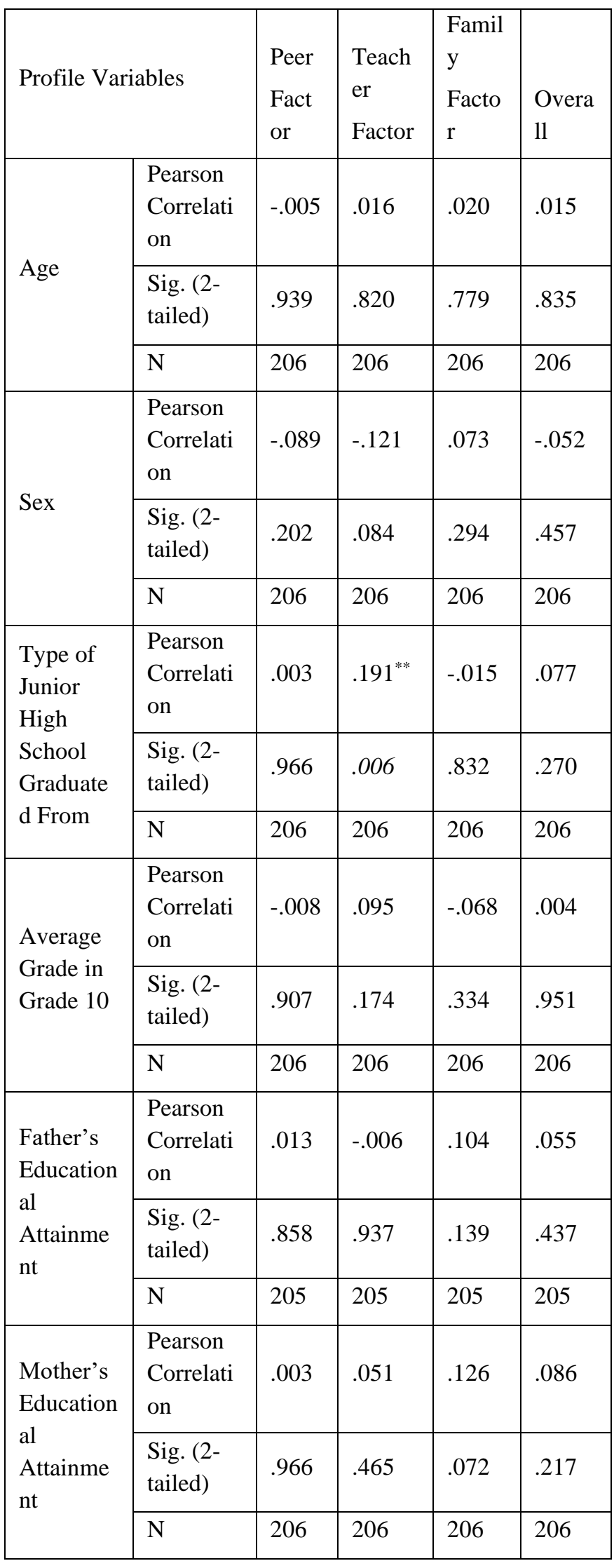

\begin{tabular}{|c|c|c|c|c|c|}
\hline \multirow{3}{*}{$\begin{array}{l}\text { Father's } \\
\text { Occupatio } \\
\text { n }\end{array}$} & $\begin{array}{l}\text { Pearson } \\
\text { Correlati } \\
\text { on }\end{array}$ & .089 & .027 & .001 & .049 \\
\hline & $\begin{array}{l}\text { Sig. (2- } \\
\text { tailed) }\end{array}$ & .202 & .705 & .985 & .489 \\
\hline & $\mathrm{N}$ & 205 & 205 & 205 & 205 \\
\hline \multirow{3}{*}{$\begin{array}{l}\text { Mother's } \\
\text { Occupatio } \\
\text { n }\end{array}$} & $\begin{array}{l}\text { Pearson } \\
\text { Correlati } \\
\text { on }\end{array}$ & .109 & -.067 & -.043 & -.006 \\
\hline & $\begin{array}{l}\text { Sig. (2- } \\
\text { tailed) }\end{array}$ & .118 & .339 & .542 & .928 \\
\hline & $\mathrm{N}$ & 206 & 206 & 206 & 206 \\
\hline
\end{tabular}

*Significant @.005

**Significant @.001

The third specific problem dealt with the Correlation analysis among the profile of the respondents and their non- intellective challenges in oral communication skills of grade 11 learners in Sto. Domingo National Trade School S.Y. 2017-2018.

Table 11 shows the correlation analysis using Pearson R Correlation Analysis to determine significant relationship between the profile of the respondents and their nonintellective challenges in oral communication skills.

It can be gleaned that a type of Junior High School completed from among the profiles of the respondents was correlated to one of the factors which is "Teacher Factor" by having 0.006 which is less than the value of level of significance 0.01 .

Overall, profile variables do not have any relationship to non-intellective challenges in oral communication skills by having significance level values greater than 0.05 or 0.01 . Thus, the null hypothesis "there is no relationship among the profile of the respondents and their non-intellective challenges in oral communication" is not rejected.

\section{Project Proposal To Address The Non- Intellective Challenges In Oral Communication Skills Among Grade 11 Learners}

The output of this study is to propose a project intended to address the non-intellective challenges specifically in Peer factor in oral communication of grade 11 learners. The project proposal is arrived at because it identifies specific targets which were designed based on the findings of the study. Following the format of this content may be very beneficial to grade 11 learners, teachers, and school administrators in order to develop the learner's confidence 
and overcome these non-intellective challenges in their oral communication practices.

\section{CONCLUSION}

This study attempted to determine the non- intellective challenges in oral communication skills of grade 11 learners in Sto. Domingo National Trade School during the school year 2017-2018. The data were gathered from 206 Senior High School Grade 11 learners. To determine the total respondents, the sample and sampling procedures were employed. The Descriptive method of research was applied in this study.

The Summary of findings for non-intellective challenges in oral communication skills among grade 11 leaners clearly stated that among all the non-intellective challenges encountered or experienced by the respondents, Peer Factor gave the highest challenge.

Based from the conclusion, the following are recommended:

Teachers and School Administrators may adapt the Project Proposal to address the non-intellective challenges in oral communication skills encountered by grade 11 learners. This project may help teachers, and school administrators to meet the needs of learners with poor oral communication skills. This may help them boost and understand themselves as unique individuals, develop their personality, manage speech anxiety, increase their selfconfidence, and equip themselves with competence in oral communication skills in the $21^{\text {st }}$ Century.

Lastly, future researchers may pursue similar studies dealing with intellective challenges in oral communication skills among learners.

\section{ACKNOWLEDGEMENTS}

The researchers would like to thank their families who provided so much provision and understanding in completion of this research paper.

\section{REFERENCES}

[1] Ang, J.G. (2015). Speech and Oral Communication for the $21^{\text {st }}$ Century Students (p.1). Published and Distributed by: Mindshapers CO. , INC. Rm. 8, Intramuros Corporate Plaza Bldg. Recoletos St., Inramuros, Manila.

[2] Boss, S. (2016). All Together Now (pp. 9). Retrieved from:https://www.thecommunicationtrust.org.uk/ media/ 311/ all together_now_v_2.pdf (2017, September 3)

[3] Chavez, J. D., Neri, M. N., Paguio, G. D., \& Tabotabo, C.V. (2012). Creative Oral Communication for Filipino: a Practical Application. Great Books Publishing. Quezon City.
[4] De Jesus, F. S., \& De Jesus, M. B. (2021). Spending Habits of Public School Teachers in Palayan City. Open Access Library Journal, 8(2), 1-12.

[5] Del Villa, C. P. (2010).Journal Media and Communication Studies Vol. 2(7), pp. 159-169. Retrieved from: http://www.academicjournals.org/journal/JMCS/articlefull-text-pdf/33FAB8710958 (2017, September 12)

[6] Department of Education (2017). DepEd Mission and Vision. Retrieved from http://www.deped.gov.ph/orders/do36-s-2013 (2017, October 16)

[7] Department of Education (2017).K to 12 Basic Education program. Retrieved from: https:// www.google. com.ph.(2017, October 14)

[8] Flora, I. O. (2016). Philippines 'Rice Granary' region heading toward industrialization. Sun Star Pampanga. Retrieved from http:// www.sunstar. com.ph/pampanga /localnews/2016/08/31/philippines-rice-granary-regionheading-toward-industrialization (2017, October 20)

[9] Flores, M.B. (2007). Factors Affecting students' level of proficiency in English (Master's Thesis). Bataan Peninsula State University. Bataan.

[10] Frijas, M.R. (2014). Factors Affecting the Academic Performance in English Among Senior High School Students in Public Secondary Schools in the first Congressional District of Nueva Ecija (Master's Thesis). College of the Immaculate Conception. Cabanatuan City.

[11] Gupit, F. Jr. (2011). Elements of Public Speaking Fifth Edition, Manila. Rex Book Store.

[12] Hays, J. S. (2015). Customs in the Philippines. Retrieved from

http://factsanddetails.com/southeastasia/Philippines/sub5_6 c/entry-3869.html (2017, October 21)

[13] Kraus, M.N. (2010). Stand up to bullying. Retrieved from http://nobullying.com/when-words-become-verbal-

abuse/goodre frenceonbullying-https://www.slideshare.net/victoria santos 9822924 /bullying-thesis (2017, October 21)

[14] Kukaswadia, A. (2013). The Power of Words. Retrieved from http://blogs.plos.org/publichealth/2013/01/10/thepower-of-words/ (2017, October 22)

[15] Jose, L. S., \& Larioque, R. R. (2016). Oral Communication in Context for Senior High School. Department of Education.

[16] Kolk, B., McFarlane A., and Weisaeth, L. (2007). Traumatic stress: The effects of overwhelming experience on mind, body, and society. New York: The Guildford Press. Retrieved from https://www.guilford.com/books/Traumatic-Stress /KolkMcFarlane -Weisaeth/9781572304574 (2017, June 16)

[17] Mazzerella, D. M. (2012.) Oral Communication Essay FYR. Retrieved from https://sites.google.com/ site/ deborah mazzerella /oral -communication-essay-fyr (2017, October 15)

[18] Nguyen, T. T. L. (2011). Factors Affecting the Engslish Speaking ability of Second Year students in Hanoi Tourism College (Thesis). Southern Luzon State University. Lucban Quezon, Philippines. 
[19] Nocom, N. M. (2009). Motivating factors Affecting the communication skills of college students: A basis for the propose supplementary materials (Master's Thesis). Bataan Peninsula State University.

[20] Philippine Education for All Review Report (2015). Education for All National Review. Retrieved from http://unesdoc.unesco.org/images/0023/002303/230331e.pd f (2017, October 18)

[21] Reardon, T., Valintino, M., \& Shore Y. (2013). Children, Youth, Families and Socioeconomic Status. Retrieved from http://www.apa.org/pi/ses/resources/publications/childrenfamilies.aspx (2017, October 15)

[22] Singh, Y.K. (2010). Research Methodology. Retrieved from https://books.google.com.ph (2017, July 20)

[23] Tapalla, W., \& Tapalla, V. (2009). Public Speaking and Personality Development. Pasig City Anvil Publishing Inc. 2008. vi, 250p. $22 \mathrm{~cm}$.

[24] The Bullying in the Philippines (2016). Bullying. Retrieved from https://nobullying.com/bullying-in-the-philippines/ (2017, July 5) 